\title{
The impact of Brexit on Africa in times of the Corona Crisis The case of South Africa, Nigeria, Ghana and Kenya
}

\author{
Dirk Kohnert ${ }^{1}$
}

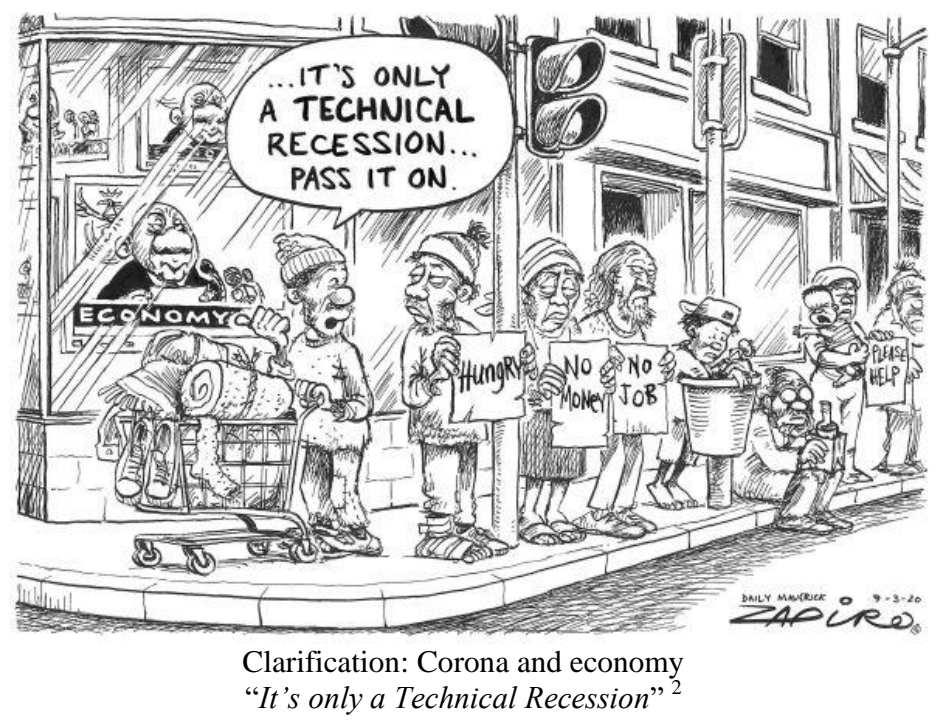

\begin{abstract}
Although Britain has been so far the hardest hit among the EU member states by the corona pandemic, Johnson persists to leave the EU at the end of 2020, whatever the cost. Presumably, the pandemic will have a by far bigger impact on the UK African trade than a nodeal Brexit. In Sub-Saharan Africa, South Africa had been arguably the hardest hit country both by Brexit and Corona. However, the poor, mainly working in the informal sector, were more concerned about the economic impact of the pandemic than the disease itself. In Nigeria, many people envisaged Corona as a plague of the rich and the elite. President Buhari shared the hubris of many British that they are less vulnerable to the pandemic and could continue with highflying Post-Brexit plans. Ghana counts among those countries in Sub-Sahara Africa which has been most severely hit by the corona pandemic. But unlike South Africa and Nigeria, the direct effects of the pandemic on the downturn of its economy are not as significant as in other African states. In Kenya the number of corona-death had been much lower than for the SARS pandemic of 2003, but the transmission of the COVID-19 virus had been significantly greater. Nevertheless, many Kenyan's saw the Brexit as a disguised blessing because they pined their hope on massive FDI by UK investors. In any case, it is clear beyond doubt that those who are to suffer most by the combined effects of the corona-pandemic and Brexit in Africa (and presumably world-wide) are the poor and needy.
\end{abstract}

Keywords: Corona, Brexit, Africa, UK, EU, international trade, economic recession, poverty, South Africa, Nigeria, Ghana, Kenya

JEL-Code: F13, F35, F54, F63, G15, I1, N17, N47, N67, O17, P16, Z13

\footnotetext{
${ }^{1}$ Dirk Kohnert, associated expert at GIGA-Hamburg, Germany. Revised version: 11 May 2021

${ }^{2}$ Cartoon on Cyril Ramaphosa's statement that SA economic recession starting in 2019 was just a technical recession. @CyrilRamaphosa, Zapiro, @zapiro, Zapiro's cartoon @ dailymaverick, (18 March 2020) $\underline{\text { https://zapiro.com/200309dm }}$
} 


\section{Introduction}

The UK's exit from the EU took place on January 31, 2020 as administered by the withdrawal agreement signed on January 24, 2020. The agreement provided for a transition period until December 31, 2020, to renegotiate the long-term relationship between the United Kingdom (UK) and the European Union. The UK initially complies with all EU rules and continues to pay contributions, but no longer has a say in EU bodies. The transition period could be extended beyond December 31, 2020 at the latest on June 30, 2020. However, a no-deal Brexit is at present more likely. The serious impact of the Brexit on the UK will be aggravated by the Corona-crisis. Although a second Corona-wave looms over the United Kingdom which threatens to aggravate the economic impact of the pandemic on the island even more, the British prime minister Boris Johnson persists to leave the EU at the end of 2020, whatever the cost.

According to the latest forecast of the Office for National Statistics (ONS, London), the monthly gross domestic product (GDP) fell by $20.4 \%$ in April 2020, the biggest fall the UK had ever seen, more than three times larger than in March and almost ten times larger than the steepest pre-COVID-19 fall. Virtually all areas of the economy were hit, with pubs, education, health and car sales giving the biggest contributions to this historic fall. Moreover, Britain's trade with the rest of the world was also badly affected by the pandemic, with large falls in both the import and export of cars, fuels, works of art and clothing (ONS, 2020). The (potential) negative economic effects of the Brexit on the UK (Brown et al, 2019; Kohnert, 2018) would further aggravate the looming economic recession. According to Andy Haldane, the chief economist of the Bank of England, mass under- and unemployment is the result. More than 8 million self-employed and other people put on leave were concerned, i.e. almost a third of all gainfully employed people in the private sector, a level never to be seen on the labour market before. More than 1.5 million more may potentially have lost their jobs, judging by new universal credit claims. About $20 \%$ of households are afraid to face significant financial difficulties as a result of the pandemic. And it is almost certain that the hardest-hit will be the poor, the lower-paid, including young people and women (Haldane, 2020). Accordingly, $68 \%$ of British adults were worried about the effect of the coronavirus (COVID-19) on their life in early June (ONS, 2020). This the more so because the Government's handling of the pandemic had resulted in the meantime in the highest Covid-19 death toll in Europe (Campbell et al, 2020).

Under these conditions, one would expect that London would be keen more than ever to profit from a potential common EU bailout for the years to come, both for the economic and the health concerned aftermath of the pandemic. This the more so, because of additional negative employment effects of Brexit. However, Johnson does not seem to care. And it is open to question whether those who voted the Prime Minister in power would act now otherwise. In fact, some politicians ventured already the guess, the British government may provoke a chaotic no-deal exit from the EU to distract from its failure in the COVID 19 crisis (Mason, 2020).

Anyway, apparently, there is a connection concerning the background-argument of both the Brexit and the handling of the corona-crisis. On 31 January 2020, the United Kingdom's membership of the European Union ended 47 years after it joined. Brexiteer arguments as well as corona-ideologists reasoning centred on fantasies about British supremacy in matters of international trade (Brexit) and its scientific and inventive genius to cope with the pandemic. Both with lots of allusions to the Second World War. However, the wartime 
analogy is deeply misleading because Brexit involves the breaking up of the regulatory and customs market and would open the British market not only to European producers but to those from all over the world. The mythical picture of British innovation applies also to the Brexiteer arguments that hinge on the UK's supposed leadership in creativity and innovation (Edgerton, 2020) and the notion that the British had no need of Europeans, or that at least "they need us more than we need them" (English, 2020). On the contrary, a no-deal Brexit could wreck the UK's chance of leading Covid-19 global research. Nobel scientists, like Sir Andre Geim at Manchester University, warned that Britain will lose 'superpower' status if access barred to the EU’s $€ 100 \mathrm{bn}$ ( $£ 85 \mathrm{bn}$ ) research funding scheme, Horizon Europe, which will run from 2021 to 2027. Since the start of the current EU scheme, Horizon 2020 (which will be succeeded by Horizon Europe), the UK has received more than $£ 1$.5bn in ERC income and $£ 776 \mathrm{~m}$ in MSCA (Marie Skłodowska Curie Actions) grants - more than any other EU country, and a fifth of the total (Helm \& McKie, 2020).

UK companies on the other hand apparently had a more realistic view and seemed to have been well aware of the looming risk. They voted already before the Corona-crisis with their money, sharp tongues would maintain, like rats deserting a sinking ship. However that may be, the Leave vote had led British firms already by March 2019 to increase the number of UK outward investment transactions in the remaining EU27 by 17\%, whereas transactions in nonEU OECD countries remained unaffected. Moreover, the Brexit-related uncertainty led to loss of market value of international firms most exposed to Brexit as well as reduced hiring and investments, because international firms overwhelmingly expected negative direct effects from Brexit. Especially, firms expected difficulties from regulatory divergence, reduced labour mobility, and limited trade access (Hassan et al 2021).

On the other hand, the number of EU27 investment projects in the UK declined only by around $9 \%$, which suggests that the UK would be more exposed to the costs of economic disintegration than the remaining EU member states (Breinlich et al 2020). By the way, no trade unions dared to equal this behaviour as 'unpatriotic'. Apparently, international mobility of capital is always welcomed as a sign of innovative adaptation in difficult times. Whereas mobility of labour is often equalled to unfair competition, as in the case of East-European labourers who tried their luck in the UK, which after all triggered the Brexit vote.

To return to the Brexit question, it is still open to question whether Britain's pious wishes concerning the replacement of the EU internal market by extended links to its former Commonwealth markets, first and foremost to the US-market, will realise. London itself was rather cautious. It estimated in early March that enhanced bilateral trade with the US could result in rather modest prosperity, by its own gross domestic product increasing between $0.07 \%$ and $0.16 \%$, but only after around 15 years. But still, the United States is only the second-largest British trading partner after the EU. Moreover, the British government had been up to date opposed to American wishes, like a complete opening of agriculture for American investors and access to the National Health Service NHS for US pharmaceutical manufacturers (Triebe, 2020). Whether London's ambitions concerning the opening-up of African markets will be more promising is even more doubtful because the remaining EU-27 does not lie low.

As for the EU, the European Commission and European External Action Service presented in early March a draft comprehensive cooperation strategy with Africa in preparation of the sixth 
EU-Africa summit in October 2020. But the Corona-crisis and its effects, not only on the EU and Africa but on the whole world, reduced these high-flying plans to shambles ${ }^{3}$.

Although Europe will be severely hit by the pandemic, Africa is likely to suffer even more. However, it may be following a different path compared with other parts of the world, according to the World Health Organization (WHO). Six months after the first African case had been detected, the rise of cases was more gradual rather than the rapid surges elsewhere in the world (Giles \& Mwai, 2020). As of 6 August 2020 the continent passed a total of one million proved cases. South Africa accounted for more than half of all cases reported, the fourth highest number of cases in the world (Giles \& Mwai, 2020). Other heavily infected countries included Egypt, Nigeria, Ghana and Algeria. By the way, even in the UK, black people are more than four times more likely to die from Covid-19 than white people, mostly due to differences in communities' wealth, health, education and living arrangements (Booth $\&$ Barr, 2020). After taking account of age and other socio-demographic characteristics and measures of self-reported health and disability at the 2011 Census, the risk of a COVID-19related death for males and females of Black ethnicity reduced to 1.9 times more likely than those of White ethnicity, according to the British Office for National Statistics (release date: 7 May 2020).

According to the World Bank, the pandemic will cost the region between US \$ 37 billion and $\$ 79$ billion. The decline of world trade due to the Corona-crisis will affects Africa through collapsing international trade and global supply chains, falling remittances and capital-flows and problems in meeting foreign currency payment obligations (Brugner \& Schuch, 2020:6).

\section{Map 1: African member countries of the Commonwealth ${ }^{4}$}

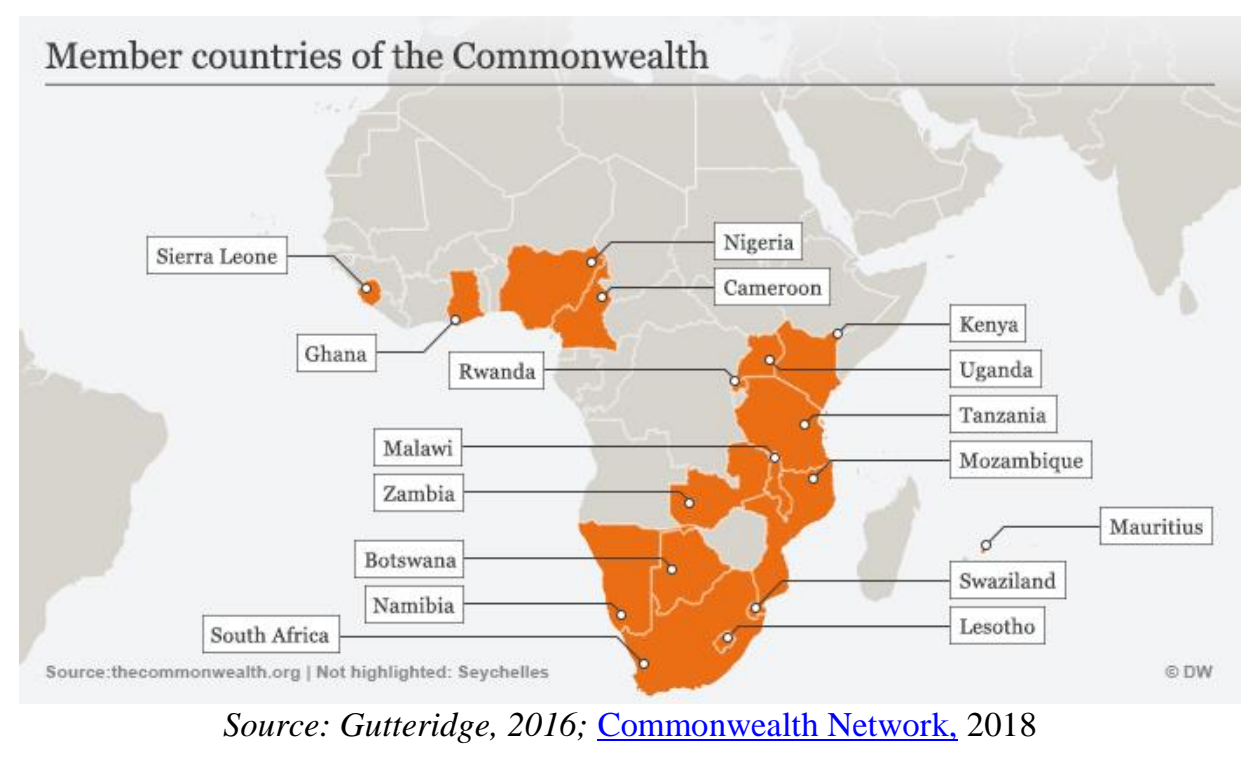

\footnotetext{
${ }^{3}$ However, the European-African Clinical Trials Partnership (EDCTP), established in 2003 to support the development of new or improved drugs and to develop capacities in Africa, may be an exception. It invested more than $€ 600 \mathrm{~m}$ since 2003 and was often perceived as a lighthouse project. It intended to finance projects with a budget of up to $€ 28 \mathrm{~m}$ from Horizon 2020 plus additional finances from its member states to enhance coronavirus pandemic preparedness in sub-Saharan Africa. This Horizon 2020 investment is in line with the EU's commitment to step up scientific cooperation with the African Union as set out in the Commission's comprehensive Africa Strategy adopted on 9 March 2020 (Brugner \& Schuch, 2020: 3).

${ }^{4}$ Gambia (West Africa, re-joined in 2018) and Seychelles, are not highlighted in the map; Zimbabwe withdraw in 2003.
} 
The largest economies in the region, among them the heavy-weights of the African Commonwealth, South Africa and Nigeria, are expected to be hit the hardest by these economic effects. The collapse of oil and commodity prices, for example, will have a devastating impact on several African economies that depend on these for more than half of their exports (Laporte, 2020). To emasculate the threatening economic recession, African finance ministers called for an economic stimulus of at least US \$100 billion to curb the impacts of coronavirus. But this will be only a drop in the bucket. Scholarly analysis showed that the average stimulus in Europe so far is 15 times higher than in poorer African countries (Laporte, 2020). Moreover, remittances dried up because of the corona-crisis with fatal consequences for poor and vulnerable (Pelz, 2020). They had increased significantly in recent years and constituted almost three times the amount of official development aid, i.e. US \$48 billion ( $€ 42$ billion) had been sent to sub-Saharan Africa in 2019. In 2020, the figure is likely to decrease to about $\$ 37$ billion ( $€ 34$ billion) because of Corona, because most African migrants in Europe are lower-skilled workers, labouring in the informal sector, e.g. in retail stores, hotels, tourism or as daily farm labourers. Many of these jobs had to cease operations due to the lockdown or social distancing measures. Remittance flows are expected to fall across all World Bank Group regions, but most notably in Europe and Central Asia (27.5 percent), followed by Sub-Saharan Africa (23.1 percent) (World Bank, 2020).

Graph 1: Remittances sent to Sub-Saharan Africa in 2018, by country (in billion U.S. dollars)

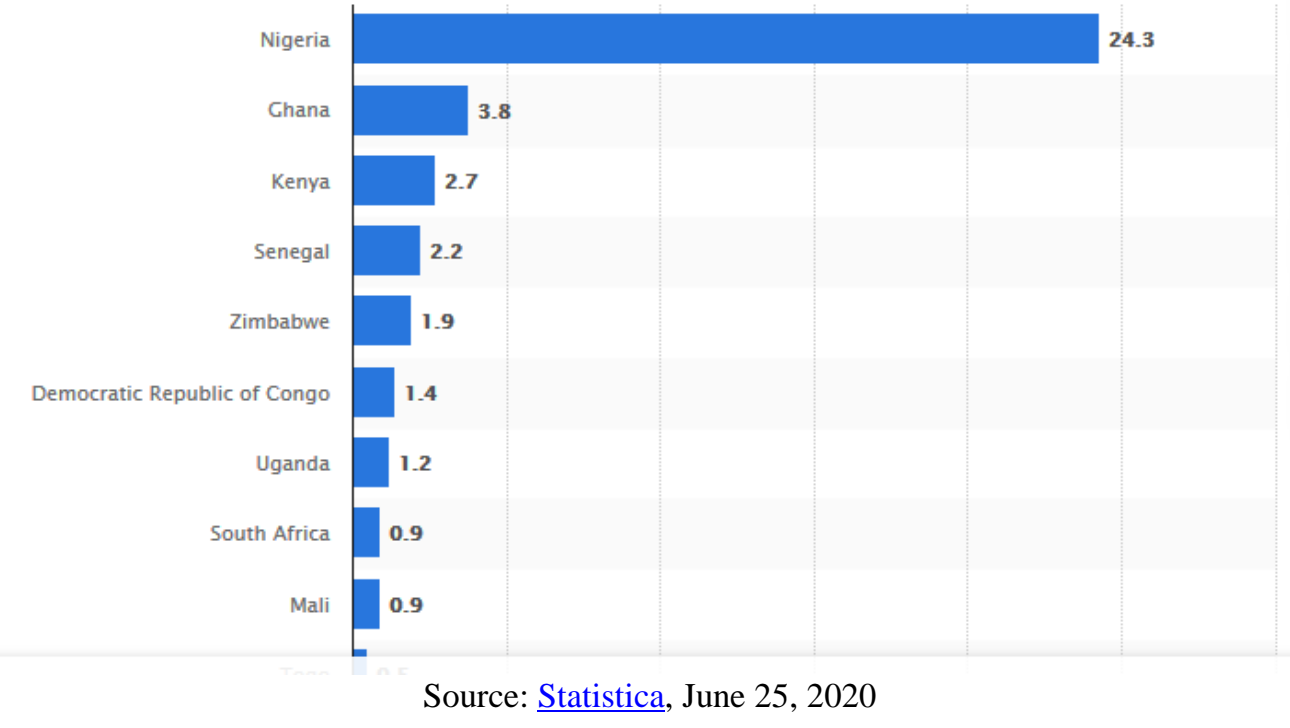

There's also rising concern about possible disruption to food supply chains because of the virus' impact on farms and food imports. Particularly concerned are those in informal jobs living hand-to-mouth. According to estimates of the African Union, nearly 20 million jobs are threatened across the entire continent. Many of them say they would rather prefer to die from Corona than from hunger (Kennedy, 2020; Bavier \& Paravicini, 2020, Schwettmann, 2020). In any case, it is clear beyond doubt that those who are to suffer most by the combined effects of the corona-pandemic and Brexit are the poor and needy.

In short, it is already questionable whether the UK will be able to pull itself up by its bootstraps out of the corona-crisis after the Brexit-leave without the tried and tested cooperation with the EU. Whether Britain, on its own, will have the additional power to assist its former African colonies to cope not only with the consequences of the corona-pandemic but also with the impact of a no-deal Brexit is even more unlikely. 


\section{Map 2 : Overview on the current state of affairs of Corona cases in Africa}

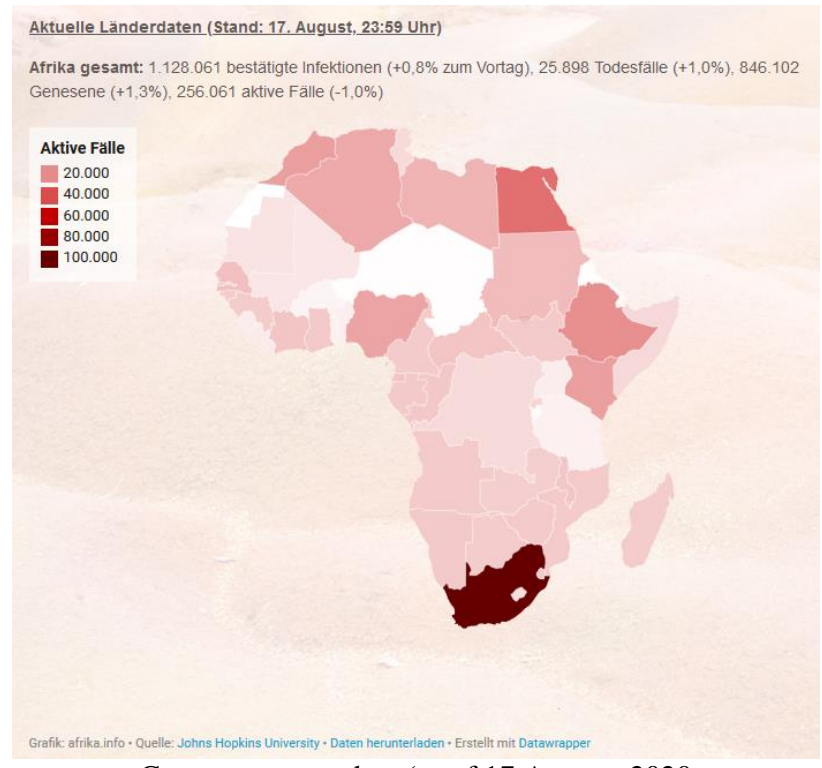

Current country data (as of 17 August, 2020

Africa total: 1.128 .061 confirmed infections $(+0.8 \%$ on the previous day), 25,898 deaths $(+1.0 \%), 846.102$ recovered people $(+1.3 \%), 256.061$ active cases (-1.0\%). Source: Daten \& Fakten: Das Coronavirus in Afrika, Salzburg: afrika-info

\section{Graph 2: How Africa's Covid-19 outbreak compares}

number of cases per day, seven day rolling average. Each region on its own scale.

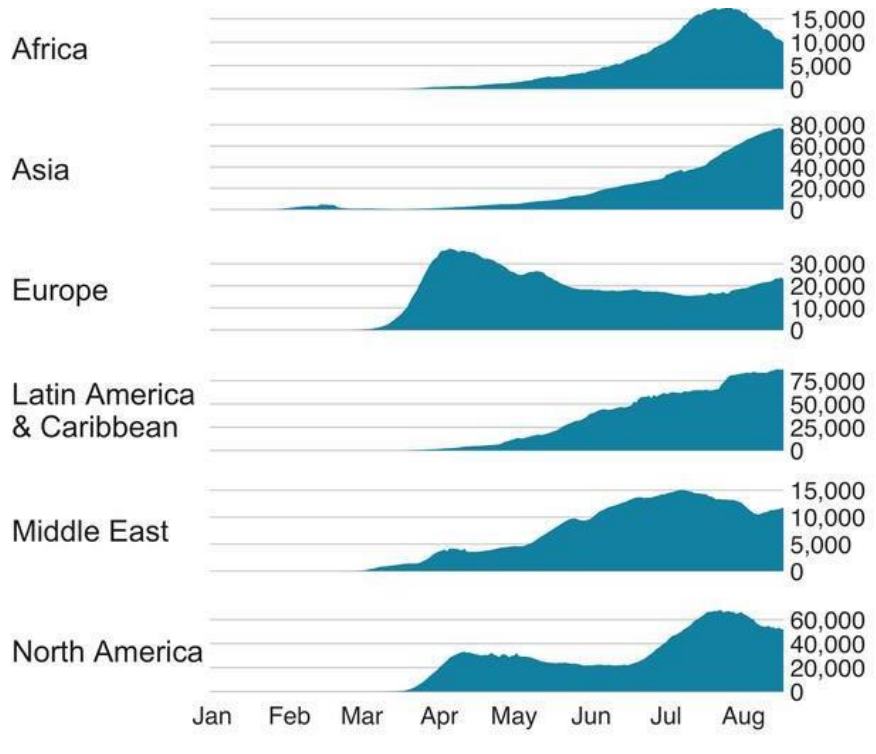

Oceania cases excluded as too low to register on scale

Source: ECDC and national public health agencies, data up to 16 August BBBC

Source: Giles \& Mwai, 2020

In the following sections a more detailed analysis of the (potential) combined effects of corona and Brexit on member states of the British Commonwealth in Africa will be given, taking the example of South Africa, Nigeria, Ghana and Kenya, with special emphasis on the impact on the most disadvantaged social strata of society. 


\section{(1) South Africa, Brexit and Corona}

\section{The impact of Corona on South Africa}

According to available data, South Africa has been one of the hardest-hit African countries.

\section{Graph 3: Rising fast}

Africa, confirmed cases of Covid-19, selected countries, up to 25 March 2020

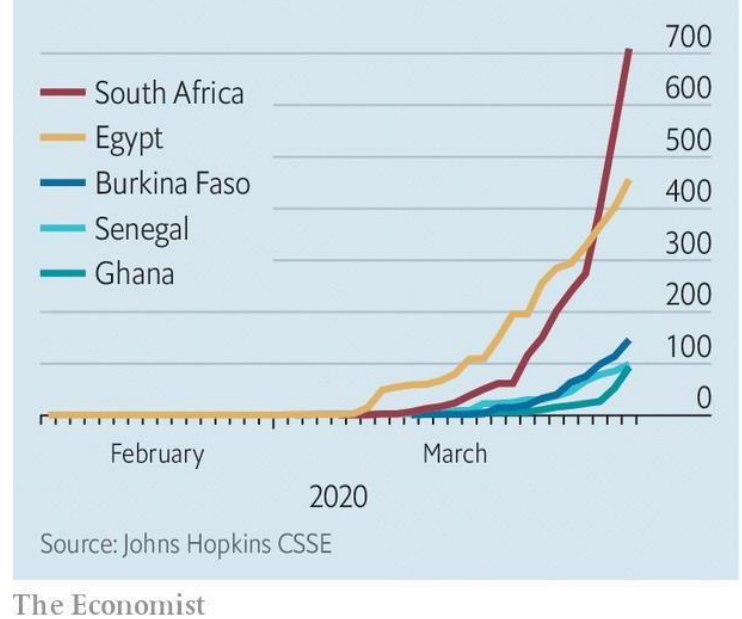

Source: The Economist, London

As of 15 June 2020, the cumulative number of confirmed COVID-19 cases in South Africa was 73,533, the bulk of it came from Western Cape Province (60\%), followed by Gauteng $(17 \%)$ and Eastern Cape (14\%). The total number of reported death was 1,568 (NDP-2020). To avoid "an enormous catastrophe", President Cyril Ramaphosa had ordered a three-week nationwide lockdown on 23 March, including border closure, the release of about 19,000 prisoners (12\% of a total of 155,000 prisoners in the jails of the country) and a ban to sale alcohol, supported by the South African army, from 26 March to 16 April (Thielke, 2020).

\section{Graph 4: Covid-19 trajectory in South Africa compared to the rest}

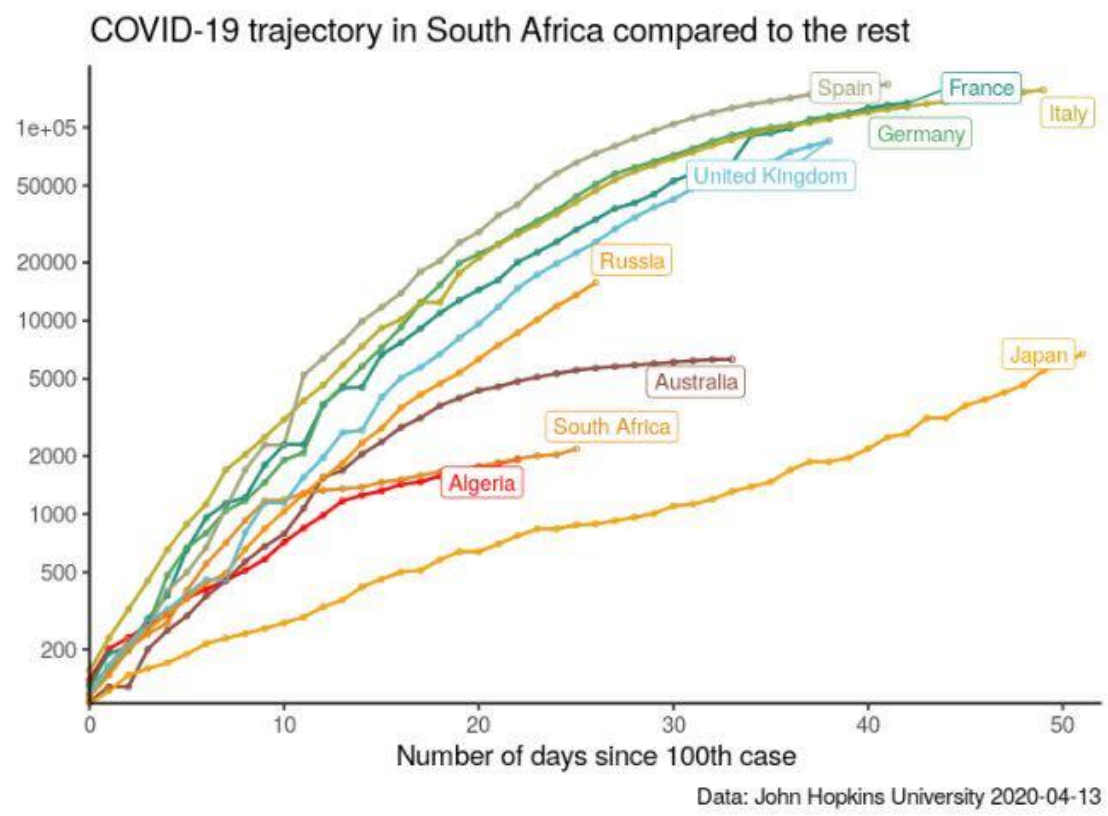

Source: South Africa's response to Covid-19 is 'world-class' and here's why. 
According to Focal Africa ${ }^{5}$ director Marcus Hollington, South Africa counted among the top five world-class corona-fighting countries, because of prompt lockdown as well as very strict social distancing measures to try and curb the virus, which made for the 'flattening of the (infection) curve' (Hollington, 2020). The deprived people living in the informal sector, notably in the townships, were it is virtually impossible to enforce social distancing and hygiene measures, were most seriously affected by corona (Schwettmann, 2020: 11).

However, most South Africans, notably the poor, mostly working in the informal sector, were more concerned about the economic impact of the pandemic than the disease itself. According to results of a Statistics-SA-survey, $93.2 \%$ of respondents $(49 \%$ of them white; $36 \%$ black Africans) were very concerned or extremely concerned about the possible economic collapse of the country due to Corona (Githahu, 2020, Schwettmann, 2020).

\section{The impact of Brexit on South Africa}

And here again, Brexit comes in, because South Africa's economy is highly dependent both on the EU and the UK which has become the fourth largest export market of the country. In 2018 SA exports to the UK amounted to about R64-billion, mainly precious metals, motor vehicles and agricultural products. SA imports from the UK attained R43.5-billion. Nevertheless, the EU remained by far the biggest trading partner. The UK accounted for merely $18 \%$ of South African EU-exports and 10\% of EU imports from South Africa (Maeko, 2020). Therefore, the government in Pretoria and its partners of the Southern African Customs Union (SACU), including members of the Southern African Development Community (SADC) and Mozambique, did their utmost to maintain normal Post-Brexit trade-relations with the EU as part of their Economic Partnership Agreement (EPA) concluded already in October 2016. At that time Britain was still an EU member linked to the EPA as well, which stipulated that more than $90 \%$ of South African goods, including wines, platinum and motor vehicles, could enter into the UK completely duty-free or partially duty-free. However, because nevertheless South Africa's car exports, would still be subject to $10 \%$ tariffs, and because the global supply chain in the automotive production would be definitely disrupted in the case of a Brexit no deal, the countries automotive industry would have been completely 'writen off' according to the former trade and industry minister in Pretoria, Rob Davies (Maeko, 2020). This was confirmed among other also by VW-South Africa, whose CEO told the press in August 2019 that if components from the EU would be no longer included in the value-added calculation because of a no-deal Brexit, import duties threaten in both directions. They would make cars - depending on the type - around 1,500 to 2,000 euros more expensive (DPA(os)-2019). This would have a tremendous impact on the South African labour market, independently from the inordinately more serious economic effects of a world-wide Coronacrisis.

\footnotetext{
${ }^{5}$ Research (FAR), Information Services, Germiston, Gauteng, South Africa, founded in 2020.
} 


\section{(2) Nigeria, Brexit and Corona}

\section{The impact of Brexit on Nigeria}

The UK-Africa investment summit in London in January 2020 provided Premier Johnson with the opportunity to explain his vision of an enhanced partnership with African countries in Post-Brexit times. However, Nigeria and the UK are not close trading partners. Nigeria accounts for less than $0.5 \%$ of the UK's trade, and it receives less than $3-4 \%$ of Nigeria's goods trade. On the contrary, UK trade is dominated by China (15\%), the US (8\%), India (12\%), and the Netherlands (8\%) which also account for around $40 \%$ of Nigeria's total goods trade (Editorial, Business traffic, 2020). Moreover, Nigeria follows a strategy of importsubstitution and "catching-up-development" and therefore prefers to strengthen its manufacturing sector itself, rather than to help Britain to boost its manufacturing sector and exports within the framework of a post-colonial division of labour where the former colony would serve as supplier of raw materials, notably oil and oil products which still account for $98 \%$ of Nigerian exports to the UK. Now, Nigeria offers to extend its agricultural exports to the UK which languished about $2 \%$ up to now, but unfortunately, agriculture is probably the last sector to which the UK would be opening up its borders. It would rather continue to protect its farmers as it had done in the past of the long history of joint UK and EU agricultural protectionism within the framework of its Common Agricultural Policy. In 2019, London indicated already that in a case of a no-deal Brexit it would reduce almost $90 \%$ of tariffs to zero, excluding, however explicitly agricultural goods such as beef and dairy, including butter which Nigeria exports to the UK. Though London promised that least developing countries would get special preferential access to the UK post-Brexit - as is the case in the EU now, Nigeria was not on the list of African countries such as Benin, Angola, and Senegal that labelled as a least developing country to which such a treatment would apply (Editorial, Business traffic, 2020).

Concerning foreign direct investment (FDI) and aid the divide between the generous promises made by Johnson and the reality is less pronounced. Without doubt, the UK will remain one of Nigeria's top foreign investors. In 2018, it contributed over 35\% of Nigeria's foreign investment which stood at US\$ 6bn (Editorial, Business traffic, 2020). At the UK-Africa Investment Summit London announced investments worth over 150 billion on projects to improve Nigeria's physical infrastructure. Today, its Department for International Development (DFID) listed 46 active projects in Nigeria, ranging from solar energy to humanitarian assistance in the North East suffering from Boko Haram terrorism.

Already two years before, in August 2018, the than Prime Minister Theresa May, on her tour of South Africa, Nigeria and Kenya, boasted of protecting nascent African industries with its Post-Brexit policy in contrast to the EU Economic Partnership Agreements. (EPA; see Kohnert, 2015). On the second day of the tour for example, she unveiled in Abuja (Nigeria) proposals to create the first U.K.-Africa FinTech Partnership in Lagos. Britain is a leading global hub for Financial Technology (FinTech) which contributes over $£ 5$ billion to the UK economy every year and Lagos is said to be at the forefront of FinTech innovation in Africa. UK-Nigeria trade was worth $£ 4.2$ billion last year and British companies including British Airways, GSK, Shell, Diageo, Unilever and Standard Chartered have long-established operations in Nigeria. Altogether 111 African companies are already listed on the London Stock Exchange. In Lagos T. May also met the leading Nigerian businessman, Aliko Dangote, and welcomed the news that he is committing to list his $\$ 10$ billion cement company on the 
London Stock Exchange (LSE). Also in 2018, oil and gas company Seplat Petroleum was committing to list its $\$ 350$ million Eurobond programme on the LSE (Little 2018).

However, all these promises might be a hard sell. In view of China's long-standing and successful Africa offensive, it is open to question what Britain could offer, what other competitors do not have already on their agenda. African leaders are in the comfortable position to choose: enhanced co-operation with China, the huge European Union bloc, the United States, or with the historically-linked United Kingdom. Most probably the Africans will play one partner off against the other, choosing the best for their clientele. Thereby, they will be well aware of the relative importance of each trading partner, which would not necessarily act in favour of the UK in view of the strong bargaining position of major competitors.

\section{The impact of Corona on Nigeria}

In Nigeria, the most populous country on the continent (about 180 million), which has the world's most people living in absolute poverty ( 87 million), the pandemic started relatively late and modest, with the first confirmed case in on 27 February 2020, of an Italian citizen in Lagos. Only on 9 March, a second case had been reported in Ogun State of a Nigerian who had contact with the Italian citizen. According to the latest available figures, there were four hundred and ninety new cases on 16 June 2020.

\section{Map 3: Spread of the corona-pandemic in Nigeria}

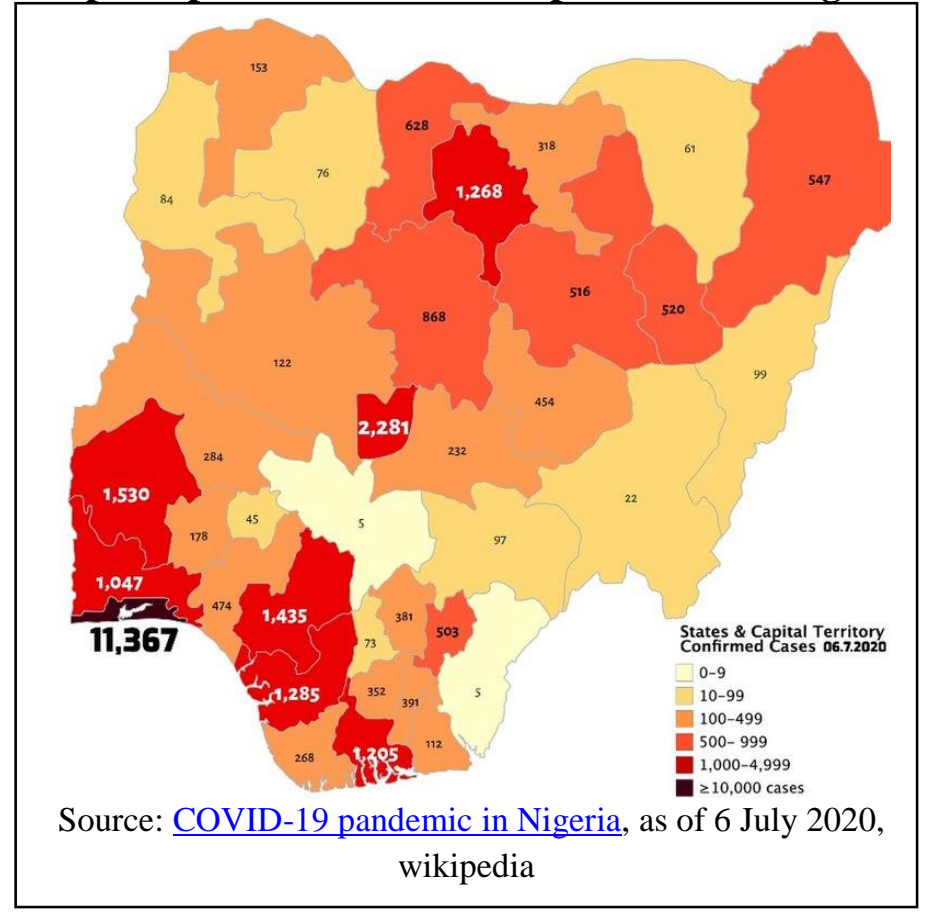

Nigerians had felt for a long time invulnerable. Until the first confirmed case of 27. February, many Nigerians saw the pandemic rather as a problem of foreigners. Past experience with Nigeria's successful fight against the Ebola virus in 2014 may have contributed to a feeling of invulnerability. Corona was dismissed by many of the Nigeria poor from Nigeria's huge informal sector as a plague of the rich and the elite - or as God's punishment for the country's decades of looting by the power-elite and therefore they hoped for salvation from the virus. The government reacted late and imposed a curfew in Lagos and the capital Abuja. Only a 
little over a month after the first Corona case had been reported, on 29 March, a curfew was imposed on the 20 million metropolis of Lagos and the capital Abuja. It was extended by another two weeks on Easter Monday. Citizens were only allowed to leave their homes to provide essentials, and economic activities declined. International and national air traffic were suspended and the national borders closed. Freedom of assembly, including religious gatherings, economic activity, and freedom of movement were restricted in most of the 36 states of Nigeria (Thum, 2020). On 1 June, the federal government relaxed the lockdown imposed on Kano State and the ban placed on religious gatherings and banking operations for a period of four weeks and also shortened the curfew from $10 \mathrm{pm}$ to 4 am (en.wikipedia). Again, Nigeria's informal economy with it estimated 56 million citizens was hit hardest by the containment measures (Schwettmann, 2020: 10-11).

At present, the Nigerian economy is on a downward slide. Only a year ago, Nigeria had emerged from a painful recession. Now economic activities were reduced under the Corona exit restrictions. Production, trade and consumption were falling, many of the coveted formal jobs will be lost and the dominant informal sector lacks revenue. Government revenue, which is derived from two-thirds from oil, is suffering from falling world market prices for crude oil, which is currently between US \$ 25 and US \$ 30 a barrel. However, the government counted in its budgeting still with US \$ 57 a barrel. This could result in underfunding of the budget by almost 50\%. The effects of the coronavirus will bring a huge downturn to the Nigerian economy in all scenarios. Besides, Nigeria faces a shortage of supply-chains for raw materials for production and other goods, as a large proportion of the goods had been stuck in Chinese ports (Thum, 2020).

However, up to now, the corona-crisis had little impact on the government Brexit strategy. Apparently, both President Muhammadu Buhari and a great lot of Nigerian people shared the hubris of the British that they are less vulnerable to the pandemic and could continue with high-flying Post-Brexit plans of a new deal with the UK. Buhari apparently shared Johnson's vision of unleashed trade within the Commonwealth and with the UK. On 20. January he maintained in an article titled "A New Case for a Commonwealth based on trade", that the long-standing bilateral relations between the two countries had been confirmed among others by the 2018 bi-lateral security pact and collaboration in anti-trafficking. A new free trade agreement would present new opportunities for both countries, notably, because Nigeria's economy would have a great deal to offer: Nigeria's vast natural energy and mineral resources, unbarred through the ending of customs barriers, could help supply the muchneeded growth stimulus for UK-companies. Greater access to the UK would also give a stimulus to one of the world's fastest expanding consumer groups with considerable purchasing power, the Nigerian middle class. On the other hand, the greater engagement of the UK in Nigeria's economy would bring jobs to under-tapped sectors, such as agriculture and manufacturing. Millions of highly skilled, English-speaking but underemployed young Nigerians, were eager to work but hitherto without the opportunities that foreign investment could bring to create jobs and build businesses. Buhari finally suggested close cooperation would be especially promising because both countries could better align regulations on investment, certification and trade because member countries' national laws were built on the same principles of English jurisprudence. On the other hand, he cautioned that, while many Nigerians in the African Diaspora enjoy considerable benefits from living in the West, they do not always feel at the heart of the community of their host country. Therefore, visa restrictions and customs barriers should be reduced (Olaniyi, 2020). The Nigerians in the Diaspora Commission (NIDCOM) even saw the Brexit as an opportunity for Nigeria to harness human capital for her development in the UK. According to them, Nigeria should key into this by 
sending trade delegations to Britain to bring her investments in human capital home (TaiwoObalonye, 2020).

However, the demand for lifting visa restrictions for Nigerians will be met with little response both by Johnson and British workers who presumably would be afraid of 'unfair competition' by the many informal low-paid Nigerians in their country and the latter's bad repute as drug dealers and criminals. Presently there are up to 300,000 Nigerians and Britons of Nigerian descent resident in Britain. Many of them were apparently already afraid of a backlash against immigrants in Britain in which Nigerians and other foreigners would be targeted after PostBrexit times when the British have had their wish stemming the tide of immigrants to Britain (N.A., 2020).

\section{(3) Ghana, Brexit and Corona}

\section{The impact of Brexit on Ghana}

The economic impact of Brexit on Ghana will be most serious in trade, foreign direct investment (FDI) and migration (remittances). Indirect political effects could include the loss of an ardent advocate within the EU, because the UK would no longer shape and lead some of the most important initiatives on the African continent that form the basis of co-operation between Europe and the continent (Ghanaian Times Editorial, 2020; Appiah-Kubi, 2019). Moreover, the interim Economic Partnership Agreement (EPA) signed in August 2016 by Ghana which allowed for the export of goods to EU, including the UK, quota-free and without payment of tariffs, would have to be renegotiated by London, in case of a no-deal Brexit. To avoid disruption, Ghana could join countries such as those under the Common Market for Eastern and Southern Africa (COMESA, made up of 21 countries, including Kenya, Egypt, Ethiopia and Rwanda) that had signed an agreement with the UK to enjoy some trade concessions just as they enjoy under the EPA (Appiah-Kubi, 2019).

Hitherto, Ghana's exports to the UK amounted to US\$ 329.47 million after having declined successively from about US\$350 million in 2011, and its imports to US\$ 1.1 billion (2017, latest available figures; Appiah-Kubi, 2019). Whether Ghana could substitute a significant part of potential loss by a relocation of its trade to the newly created African Continental Free Trade Area (CFTA) is questionable. However, since Ghanaian exports to the UK represented only about $2 \%$ of Ghana's total exports (and about $6.3 \%$ of imports) in 2017, the potential loss because of Brexit should be bearable. In medium term, Brexit could weaken trade among the UK, EU and Africa, including Ghana, because London would have to renegotiate new trade agreements with Ghana and the ECOWAS which will be costly and time-consuming. Concerning FDI, Britain ranked as fifth largest source in Ghana, with a total value of US\$ 87.1 million in 2018 (Appiah-Kubi, 2019). The likely contraction in the UK economy because of the combined effects of Brexit and Coroana will result in a significant downturn of British investments in Ghana. This negative effect will be increased by a likely reduction of remittances. The pressure on Johnson to deliver could result in further restrictions of visas and visits of Ghanaians allowed to enter the UK which would negatively impact on remittances as well, which amounted to a total of US\$ 1.97 billion for Ghana in 2017, including $21.82 \%$ (US\$ 429.5 million) from Britain (Appiah-Kubi, 2019; Hawkson, 2019).

However, although Britain is proud of its strong bilateral relations with the Commonwealth network, these relations, especially with the most important African players, South Africa, 
Nigeria, Ghana and Kenya, have been not without tensions, for example concerning braindrain (including health workers) from the former British colonies to the UK15. Last, but not least, it is unlikely that new and better deals both between Britain and Africa and between the EU and Africa (as a consequence of Brexit) would come soon as both would have to concentrate first on their most important global partners and competitors (Westcott, 2018).

The impact of Corona on Ghana

Figure 1: Daily new COVID-19 cases in Ghana, March to June 2020

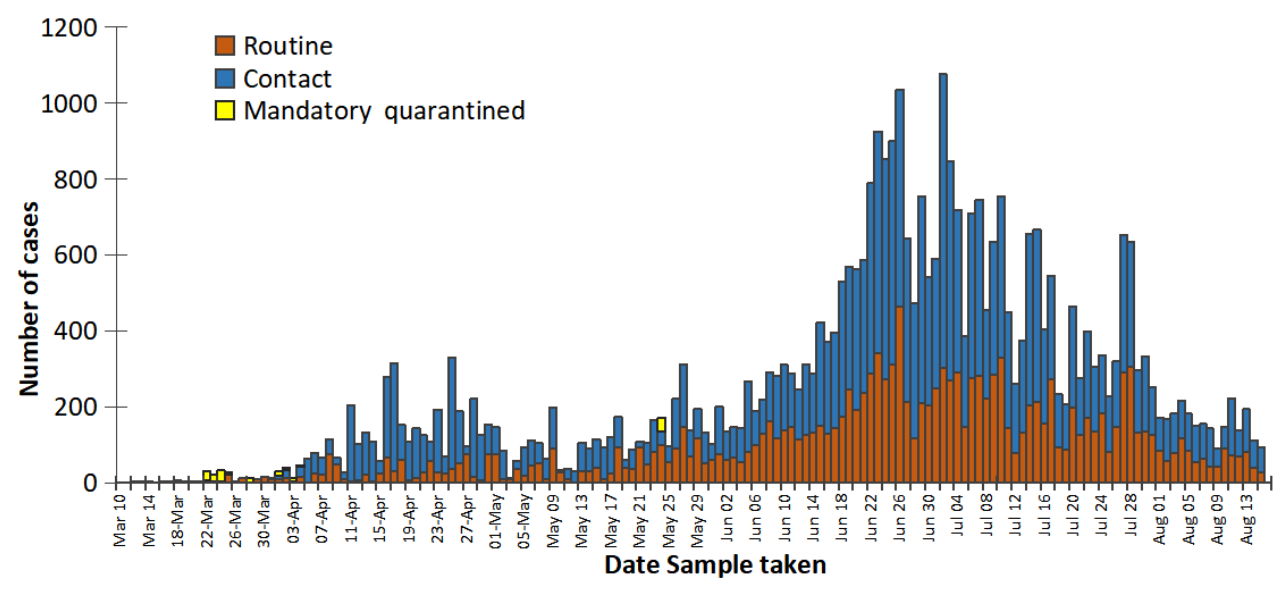

Figure 1: Distribution of COVID-19 cases in Ghana by date sample taken, March - August 2020

Source: Situation update, COVID-19 outbreak in Ghana as of 15 August 2020 Ghanian Health Service, Accra

Figure 2: Total Coronavirus deaths in Ghana, February to June 2020 (linear scale, moving 6-day average)

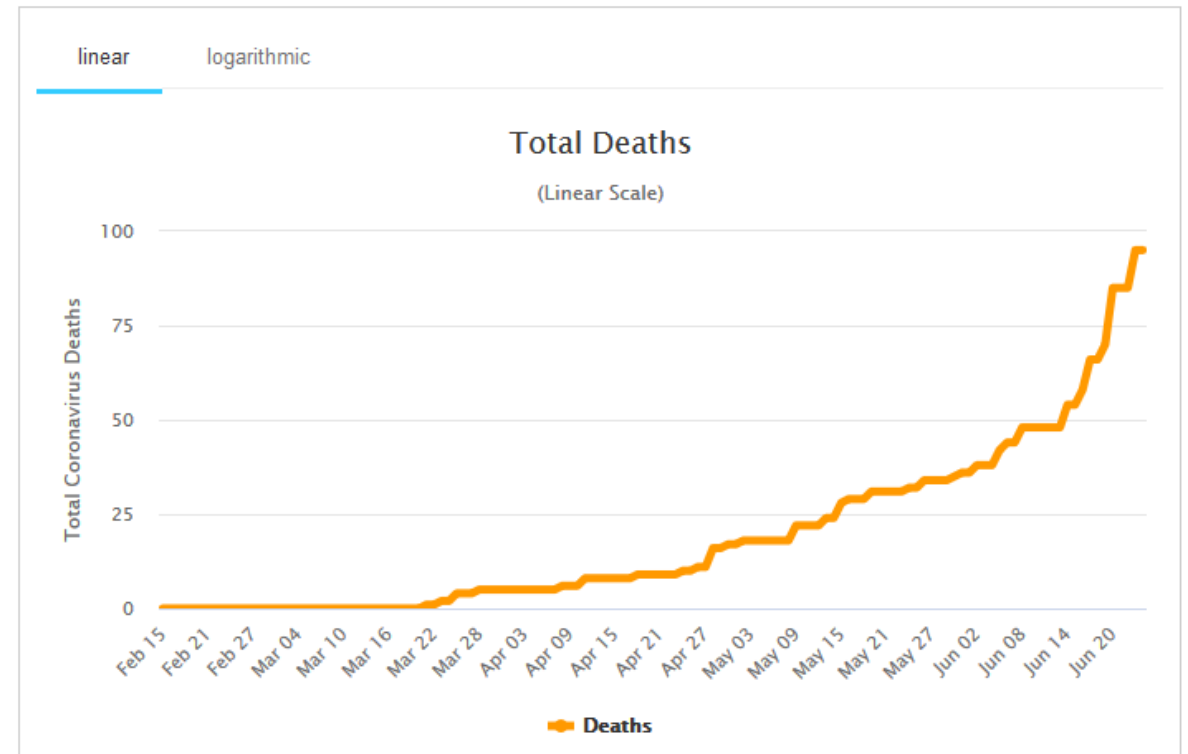

Source: Worldometer, Coronavirus, countries, Ghana, as at June 25, 2020

As of 15 August, Ghana counts with 42,993 reported cases among the three top 'spreaders' of the Corona virus in Sub-Saharan Africa, beside South Africa (101 590) and Nigeria (2,091). 
The evolution of the COVID-19 cases as well as the number of death in Ghana from March to June 2020 is shown in Figure 1 and 2.

The gender-distribution of Corona cases is unequal with significantly more male (59\%) persons infected than females (41\%) (Source: Ghana Health Service, Accra, June 25, 2020).

As for the regional distribution of cases, most of it are concentrated in the urban areas of Greater Accra and of the capitals of Ashanti and Western region (Table 3).

Graph 1: Regional distribution of confirmed COVID-19 cases in Ghana, as at June 25, 2020

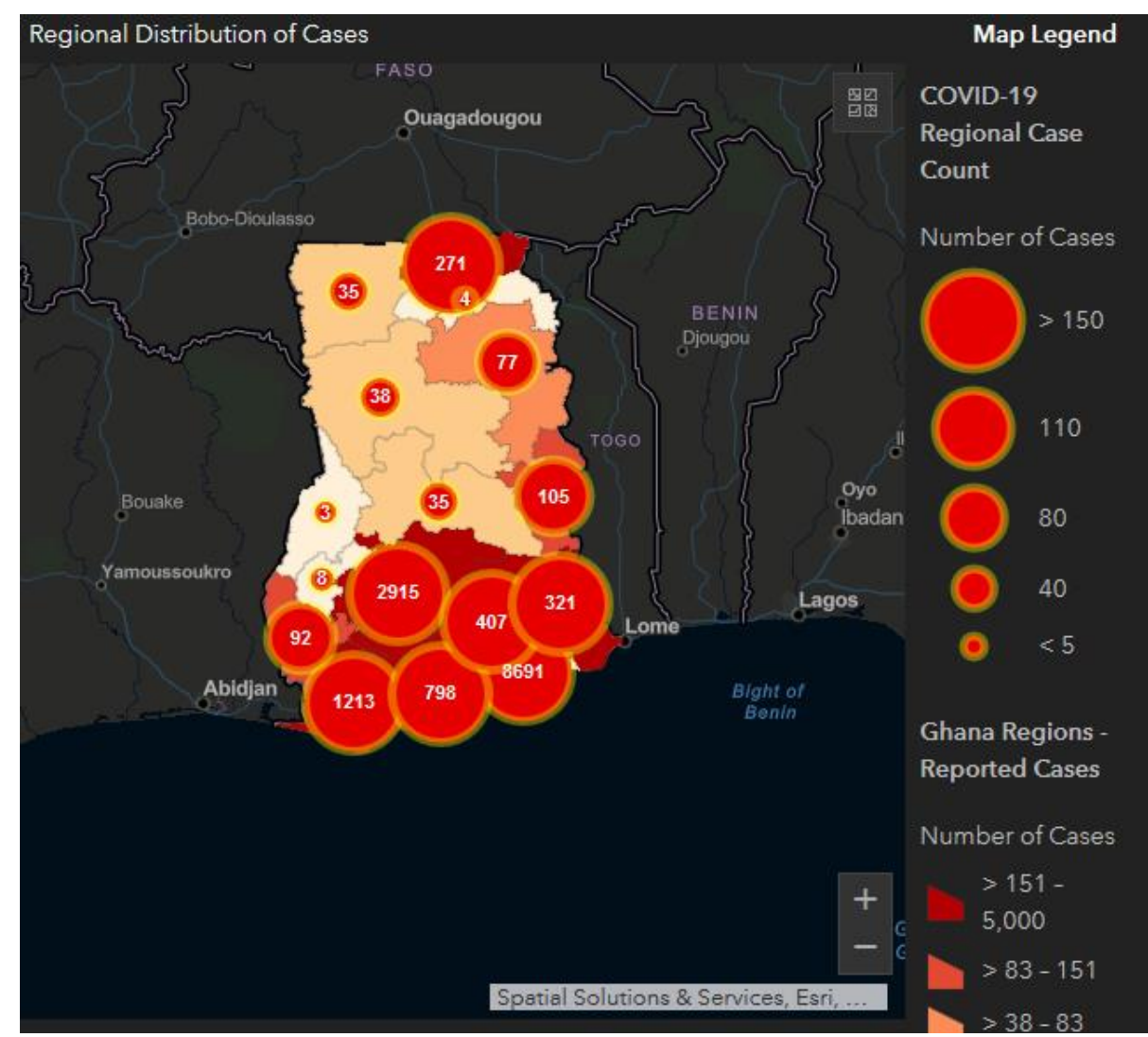

Source: Situation update, COVID-19 outbreak in Ghana as at June 25, 2020

Ghanian Health Service, Accra

A recent detailed study of the Ministry of Finance in Accra on the expected impact of the COVID 19 outbreak on Ghana's economy and government's finances resulted in a gloomy perspective, although the peak of the pandemic apparently has not yet been reached. There is likely to be a significant slowdown in GDP growth, induced among others by important shortfalls in petroleum revenues, import duties and other tax revenues, increased health expenditures, and tighter financing conditions (Team 1, 2020). The study differentiated between the direct and indirect effects: Directly, the pandemic impacts on domestic production and trade, as well as international trade and investment, notably with China, the major source of Ghana's imports, and the second highest destination for Ghana's exports, but also to Europe and the United States. Moreover, it will impact on global commodity prices (crude oil, gold, and cocoa), significant decline in the international price of crude oil as result of fall in demand (especially China). The price of crude oil declined already from US\$ 63.21 a barrel in November 2019 to US\$22.9 per barrel as at 30thMarch 2020. In addition, cocoa prices declined from US\$ 2,440 MT in December 2019 to US\$ 2,253 MT as at 30thMarch, 
2020. However, the increased demand for Gold as a safe haven will likely impact positively on the balance of payments and receipts from mineral royalties. Gold prices have increased from US\$1,479/toz in December 2019 to US\$ 1,621.6/toz, an increase of 9.6\% as at 30th March 2020 (Team 1, 2020). Indirectly, the general global economic slow-down, the disruption of supply chains will impact on Ghana's economy negatively as well.

Table 1: Regional distribution of confirmed COVID-19 cases, recoveries and discharges Ghana, June 21, 2020

\begin{tabular}{|l|c|c|c|}
\hline \multicolumn{1}{|c|}{ Region } & Cases & $\begin{array}{c}\text { Recovered/ } \\
\text { Discharged }\end{array}$ & $\begin{array}{c}\text { \% Recovered/ } \\
\text { Discharged }\end{array}$ \\
\hline Ahafo & 8 & - & - \\
\hline Ashanti & 2,867 & 1,887 & 33 \\
\hline Bono & 3 & 1 & 48 \\
\hline Bono East & 33 & 16 & 83 \\
\hline Central & 794 & 660 & 56 \\
\hline Eastem & 400 & 223 & 77 \\
\hline Greater Accra & 8,407 & 6,485 & 100 \\
\hline Northem & 61 & 61 & 30 \\
\hline North East & 3 & 2 & 100 \\
\hline Oti & 105 & 32 & 8 \\
\hline Savarnah & 37 & 37 & 100 \\
\hline Upper East & 271 & 23 & 89 \\
\hline Upper West & 35 & 35 & 96 \\
\hline Volta & 314 & 281 & 79 \\
\hline Westem & 1,148 & 1,099 & $\mathbf{7 5}$ \\
\hline Westem North & 82 & $\mathbf{1 0 , 9 0 7}$ & \\
\hline TOTAL & $\mathbf{1 4 5 6 8}$ & & 65 \\
\hline
\end{tabular}

Source: Situation update, COVID-19 outbreak in Ghana as at 21 June 2020

Ghanian Health Service, Accra

The combined economic effect of Brexit and Corona on Ghana will be a substantial decrease of economic growth and well-being of the Ghanaian people. As usual, the overall negative impact will be felt severely, not only concerning the fiscal stance, but also on human life, especially the health and life of the poor and vulnerable..

\section{(4) Kenya, Brexit and Corona}

The corona pandemic started in Kenya on 15 March with the first cases reported in the capital city Nairobi and the coastal area Mombasa county. Although the case fatality ratio for COVID-19 had been much lower than for the SARS pandemic of 2003, the transmission of the COVID-19 virus had been significantly greater, including a significant total death toll. (COVID-19 pandemic in Kenya, Wikipedia). The latest COVID-19 update (16 June 2020) revealed a total of 3,860 confirmed cases and 105 death. In April, the following distribution of the 133 positive cases reported had been as follows: in Nairobi (86 cases), Mombasa (27), Kiambu (7), Busia (5), Kilifi, Kajiado, and Migori two cases each while Machakos and Muranga, had one case each. Kenya's National Emergency Response Committee imposed social distancing requirements, closed bars and banned religious gatherings. Restaurants were to remain open only for take-away service. A daily curfew, effective from 27 March, from 7 p.m. to 5 a.m. was in effect in the whole country. The same evening the curfew had been announced, police officers in Mombasa hunted commuters who had not made it home in time. They drove men, women and children together with tear gas and truncheons, the government 
condoned the action (Starzmann, 2020). On 16 June, the government extended closing hours of restaurants and hotels from 5.00 p.m to 7.30 p.m daily with a stern warning that those who break the law will have their operating licences revoked (Ministry of Health, Nairobi, Kenya). In early May, the IMF approved US \$ 739 million to be drawn under the Rapid Credit Facility to support the authorities' response to the COVID-19 pandemic. The rising COVID-19 cases prompted the government to declare a lock-down in Nairobi's Eastleigh and Old Town region in Mombasa (Market Watch, 2020).

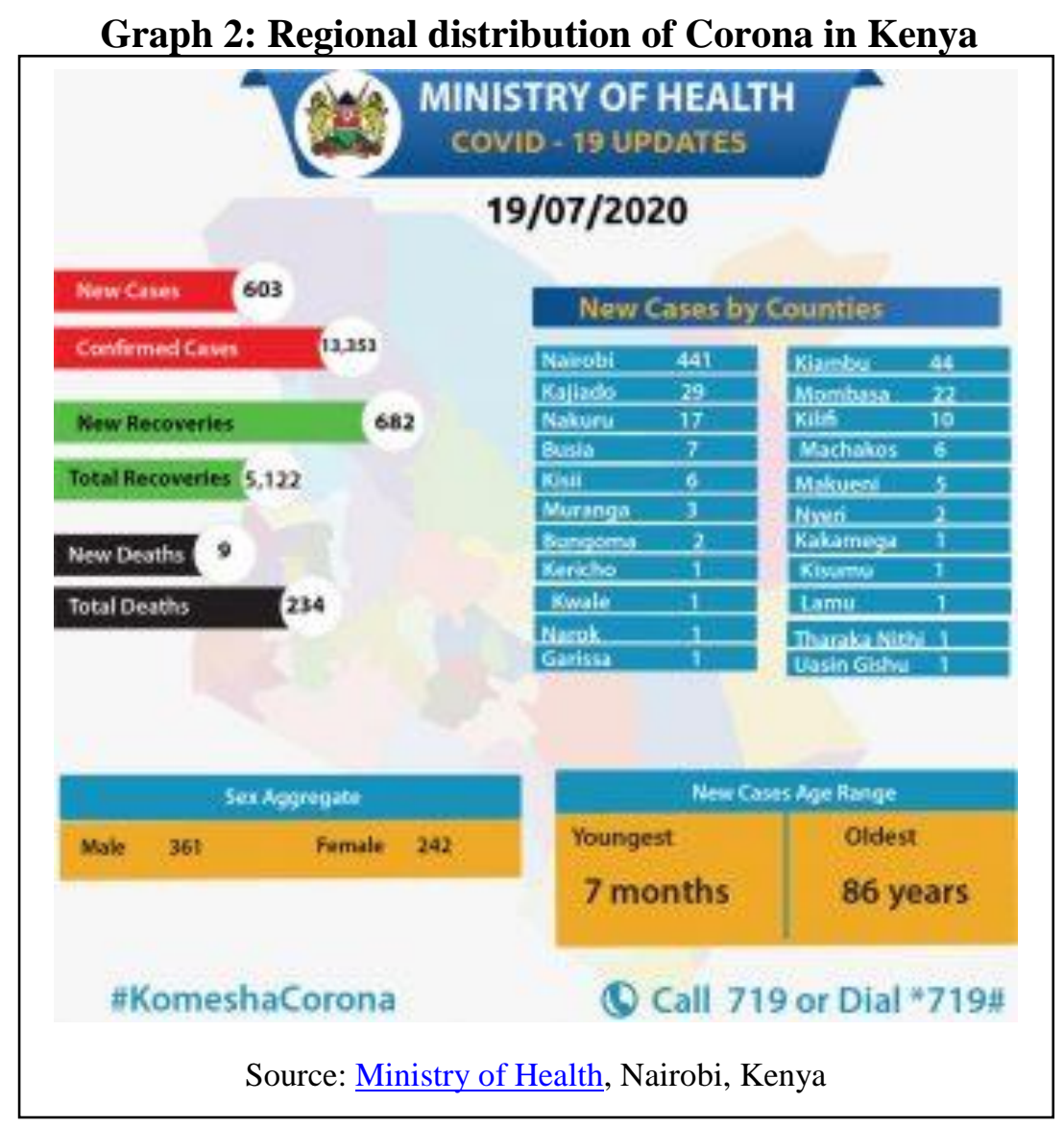

At the end of March, the Kenyan government imposed a curfew at night to contain the pandemic. Like in most African countries, the rescue packages introduced by the Nairobi government largely exclude the informal sector. More than $80 \%$ of Kenyans work as day labourers. The curfew at night, closed bars and restaurants already mean that many no longer earn anything (DW, 2020). This implicated serious economic, social and security consequences given the large numbers of women, youth and disadvantaged workers. The informal sector is the survival space for the majority of the 800,000 unemployed young job seekers who enter the Kenyan job market every year. The jobs in this sector are precarious, with limited wage and employment security, limited access to health services and social protection including weak frameworks for occupational safety and health. This makes the workers highly exposed to income loss and layoffs arising from the COVID-19 shocks (Omolo, 2020; Schwettmann, 2020:9-10).

Apparently, the corona pandemic had up to now little impact on Kenya's view on the Brexit issue. Many Kenyan's saw the UK's departure from the EU as a disguised blessing because UK investors presumably would look for strongly growing countries like Kenya that could both trade with the UK and were also unaffected by the EU's imminent restrictions for the UK (Hopkins, 2020). However, immigration from countries outside the EU such as Kenya 
into the UK would become more difficult. After all, the anti-immigration attitude was at the root of the disaffection among many Brexit voters. The anti-immigration lobby was essentially racist. On the other hand, just then when the UK was the hardest hit by the pandemic, the British National Health Service desperately needs medical staff such as nurses for which Kenya had been a source for years. But that will be harder to realize now. London would have to get its priorities right, it will have to renegotiate first at least 700 trade agreements with the 27 European nations, that Kenya would get priority is rather unlikely (Hopkins, 2020).

Moreover, with the Post-Brexit scenario, Kenya would run the risk of losing business with both partners, the EU and UK. Up to now, the UK was part of close to 40 trade agreements which the EU has with more than 70 countries. Kenya's exports to the EU rose from Sh125.61 billion in 2018 to Sh131.20 billion in 2019. Whereas Kenya's exports to the UK increased only from Sh38.55 billion to Sh40.19 billion over the same period. Imports from the UK and EU increased to Sh31.55 billion and Sh219.60 billion respectively in 2018 (Kivuva, 2019).

Hitherto, major challenges hindering the growth of Kenya's SMEs had been the limited access to finance and slow incorporation of latest technologies, as well as unawareness of international standards and quality assurance, and lack of research and innovation on new products. All this would drag the country from competing at the global market level (Kivuva, 2019). However, the Kenyan government remained confident that the Commonwealth would provide trade-related assistance and innovations, e.g. in relation to Free Trade Area, through funding to make transactions faster and increase efficiencies. According to the Commonwealth secretary-general, Patricia Scotland, Commonwealth countries enjoy 19\% in cost advantage when measured against comparable country pairs. According to her highflying visions, the intra-Commonwealth trade and investment are set to increase to Sh202.6 trillion ( $\$ 2$ trillion) by 2030 . Just in comparison, in 2017, trade in goods and services was about Sh56.7 trillion (US \$ 560 billion; Kivuva, 2019). In January 2020, Prime Minister Johnson hailed trade ties with Kenya, when he positioned the UK during the UK-Africa Investment Summit in London as an important investment partner to Africa after Brexit. He cited his country's US \$53 million investment at the Mombasa Port in 2013 as an example of a relationship benefiting all parties involved. Moreover, Kenya, secured under the leadership of its President Uhuru Kenyatta, over Sh170 billion worth of investment deals during the summit in sectors such as housing and entrepreneurship. Besides, the country's first green bond was listed at the London Stock Exchange. And finally, alcohol producer Diageo promised to invest Sh21.9 billion to build environment-friendly breweries in Kenya and wider East Africa. The firm had already invested Sh14 billion in a Kisumu keg plant (Wambu, 2020). However, Kenyan observers cautioned already, that if the British economy would crash as a result of a poorly planned Brexit, a dangerous double blow would hit Kenyan exporters. There would be less to sell, and a higher tariff to pay for the privilege of belonging to the Post-Brexit Commonwealth. Therefore, Kenya would be well advised to aligning with partners worldwide (Munuhe, 2019).

\section{Conclusion}

Although Britain had been so far the hardest hit by the Corona pandemic among the EU member states, and a second Corona-wave looms already over the United Kingdom which threatens to aggravate the economic impact of the pandemic on the island even more, the British prime minister Boris Johnson persists to leave the EU at the end of 2020, whatever the cost. The monthly gross domestic product (GDP) fell by 20.4\% in April 2020, the biggest fall 
the UK had ever seen, more than three times larger than in March and almost ten times larger than the steepest pre-COVID-19 fall. Under these conditions it is already questionable whether the UK will be able to pull itself up by its bootstraps out of the corona-crisis after the Brexit-leave without the tried and tested cooperation with the EU. Whether Britain, on its own, will have the additional power to assist its former African colonies to cope not only with the consequences of the corona-pandemic but also with the impact of a no-deal Brexit is even more unlikely. Under these conditions, one would expect that London would be keen more than ever to profit from a potential common EU bailout for the years to come, both for the economic and the health concerned aftermath of the pandemic. This the more so, because of the likely additional negative employment effects of Brexit. However, Johnson does not seem to care. And it is open to question whether those who voted the Prime Minister in power would act now otherwise. In fact, some politicians ventured already the guess, the British government may provoke a chaotic no-deal exit from the EU to distract from its failure in the COVID 19 crisis (Mason, 2020).

However, there are still many open questions, notably on the overall-effect of Brexit in relation to the world-wide impact of the Corona crisis. Presumably, the latter will have a by far bigger impact on international trade, especially with Africa. In addition, the relative weight of the UK vis à vis other global players like China and India, and even the EU will diminish in the medium and long-term. And after all, the new global focus of international trade will be reallocated from the Atlantic (America and Europe) to the Asian Pacific region, the key player in world economics to come.

In Sub-Saharan Africa, South Africa had been arguably the hardest hit country both by Brexit and Corona. However, most citizens, notably the poor, mainly working in the informal sector, were more concerned about the economic impact of the pandemic than the disease itself. However, the combined effects of Brexit and Corona are likely to have a tremendous impact, notably on the car-industry and the South African labour market, independently from the inordinately more serious economic effects of a world-wide Corona-crisis.

In Nigeria, the most populous country on the continent, the pandemic started relatively late and modest, although most people living in absolute poverty. In the beginning, the latter envisaged Corona as a plague of the rich and the elite and as God's punishment for the country's decades of looting and the hoped-for salvation from the virus. Economic activities were reduced under the Corona exit restrictions. Production, trade and consumption were falling, many of the coveted formal jobs will be lost and the dominant informal sector lacks revenue. President Buhari and a great lot of Nigerian people shared the hubris of the British that they are less vulnerable to the pandemic and could continue with high-flying Post-Brexit plans of a new deal with the UK, including unleashed trade within the Commonwealth and with the UK.

Ghana counts among those countries in Sub-Sahara Africa which has been most severely hit by the corona pandemic. As in general all over the world, the gender-distribution of Corona is unequal with significantly more male persons infected than females. But unlike South Africa and Nigeria, the direct effects of the pandemic on the downturn of its economy are not as significant as in other African states because of its favourable resource base and the effective anti-Corona measures of the government.

In Kenya the case fatality ratio for COVID-19 had been much lower than for the SARS pandemic of 2003, but the transmission of the COVID-19 virus had been significantly greater, including a significant total death toll. Nevertheless, many Kenyan's saw the UK's departure 
from the EU as a disguised blessing because UK investors presumably would look for strongly growing countries that could both trade with the UK and were also unaffected by the EU's imminent restrictions for the UK.

In a nutshell, it is clear beyond doubt that those who are to suffer most by the combined effects of the corona-pandemic and Brexit in Africa (and presumably world-wide) are the poor and needy. 


\section{References}

Appiah-Kubi, Kojo (2019): Brexit And Its Potential Impact On Ghana. Accra: Modern Ghana (MG), September 5, 2019

Anachi, E. T. (2020) The Brexit: A Massive Setback for European Union and a Lesson for African Integration. Chinese Political Science Review, volume 5, pp. 13-30 (Published 3 January 2020)

Bavier, Joe and Giulia Paravicini (2020): Africa could lose 20 million jobs due to pandemic: AU study. London: Reuters, 5 April 2020. “

Booth, Robert and Caelainn Barr (2020): Black people four times more likely to die from Covid-19. London: The Guardian, 7 May 2020

Breinlich, Holger et al (2020): Voting with their money: Brexit and outward investment by UK firms. European Economic Review, Volume 124, May 2020, https://doi.org/10.1016/j.euroecorev.2020.103400

Brugner, Philipp \& Klaus Schuch (2020): The EU's global response to the COVID-19 crisis with a focus on the Eastern Neighbourhood and Africa. Vienna: Österreichische Gesellschaft für Europapolitik, ÖGfE Policy Brief, 13'2020, 3 June 2020

Campbell, Denis et al (2020): Calls for inquiry as UK reports highest Covid-19 death toll in Europe. London: The Guardian, 5 May 2020

DPA (OS) (2019): Mögliche Folgen eines No-Deal-Brexit werden weltweit mit Sorge gesehen. Auch VW South Africa würde es wohl hart treffen. Automobilwoche, 31 August 2019

DW (2020): Brexit-Übergangsphase länger als gedacht?. Bonn: Deutsche Welle (radio)

Edgerton, David (2020): British exceptionalism: Where Brexit and our coronavirus response collide. London: The New European, 3 May 2020

(Editorial, 2020): The Impact of Brexit on Nigeria. Lagos: Business traffic, The editor, January 31, 2020

English, Otto (2020): Cruel Britannia: Coronavirus lays waste to British exceptionalism. Politico.eu, May 5, 2020

Giles, Christopher \& Peter Mwai (2020): Coronavirus - How fast is it spreading in Africa ? London: BBC Reality Check, 14 August 2020

Ghanaian Times Editorial: Post- BREXIT, what is in it for Ghana and Africa? Accra: : Ghanaian Times Tuesday, 4 February 2020

Githahu, Mwangi (2020): Stats SA: More concerned about Covid-19 impact on economy than virus itself. Cape Town: IOL, Independent Media (Pty) Ltd, May 5, 2020

Gutteridge, Nick (2016): Africa waits for UK's Brexit. London: Black Economics, Sept.22, 2016

Haldane, Andy (2020) Numeracy skills are vital as we emerge from the coronavirus crisis. London: The Guardian, 13 May 2020 
Hawkson, Emmanuel Ebo (2019): The effect of Brexit on Ghana. Accra: Daily Graphic, Aug 15 , 2019

Helm, Toby \& Robin McKie (2020): No-deal Brexit could wreck UK's chance of leading Covid-19 global research. London: The Guardian, 3 May 2020

Hollington, Marcus (2020): South Africa's world-class fight against Covid19: The data tells the story. Sandown: 947-radio, Sandown, Gauteng

Hopkins, Michael (2020): Here is what BREXIT means for Kenya. Nairobi: Standard digital, 2 February, 2020

Kennedy, Merrit (2020): World Bank: Coronavirus Is Pushing Sub-Saharan Africa To First Recession In 25 Years. npr.org, April 9, 2020

Kivuva, Elisabeth (2019): Kenya keenly watching Brexit move - Munya. Nairobi: The Star, 29 May 2019

Kohnert, Dirk (2018): More equitable British post-Brexit Africa relations: doomed to fail?, Africa Spectrum, vol. 53., No. 2, pp. 119-130 ;

Laporte, Geert (2020): Europe-Africa relations after Corona. Brussels: European Think Tanks Group (ETTG) / ECDPM, 6 April 2020.

Little, Alison (2018), May forges African alliance as London prepares for deeper ties with Nigeria after Brexit. London: Express (Daily and Sunday Express, newspaper), August 29, 2018.

Maeko, Thando (2020): Is SA ready for Bojo's no-deal Brexit? Mail \& Guardian, SA, 22 Aug 2019

Mangisa, S., Das, S., \& Gupta, R. (2020). Analysing the Impact of Brexit on Global Uncertainty Using Functional Linear Regression with Point of Impact: The Role of Currency and Equity Markets. The Singapore Economic Review. March 2021; doi:10.1142/s0217590820460029

Marbot, Olivier (2020): L'Afrique face au coronavirus : trois infographies pour mieux comprendre l’épidémie. Jeune Afrique, 25. March 2020

MarketWatch (2020): IMF Approves Sh78.3 Billion for Kenya to Address Covid-19 Pandemic. Nairobi: MarketWatch.com, May 7, 2020

Mason, Paul (2020): Inszenierte Eskalation Die britische Regierung provoziert womöglich einen chaotischen EU-Austritt ohne Deal, um von ihrem Versagen in der Covid-19-Krise abzulenken. ipg-journal, 22 May 2020

Munuhe, Faith (2019): Post Brexit, Kenya can take positive approach to grow its potential. Nairobi: Standard digital, 28th Jun 2019

N.A. (2020): Post Brexit Britain and Nigeria, Abuja: Daily Trust, (N:A.) no author given, Feb 10, 2020

NDP (2020): Covid-19 online resource and news portal. Pretoria: National Department of Health, South Africa

Nubong, Gabila (2019): Brexit and European Union Disintegration : lessons for Africa's integration Africa Growth Agenda, Vol. 16, No. 4; https://hdl.handle.net/10520/EJC-1a9a265a9b 
Olaniyi, Muideen (2020): Brexit: We want new deal with UK - Buhari. Abuya: Daily Trust, Jan 20, 2020

Omolo, Jacob (2020): How the Pandemic is affecting the informal sector in Kenya. Nairobi: FES-Blog , Friedrich Ebert Stiftung, 20 April 2020

ONS (2020): GDP monthly estimate, UK: April 2020. London: Office of National Statistics

Pelz, Daniel (2020): Coronavirus crisis disrupts flow of money transfers to Africa. Bonn: Deutsche Welle (DW), 23. May 2020

Ross Brown, Jose Liñares-Zegarra \& John O. S. Wilson (2019) The (potential) impact of Brexit on UK SMEs: regional evidence and public policy implications, Regional Studies, 53:5, 761-770, DOI: $\underline{10.1080 / 00343404.2019 .1597267}$

Schwettmann, Jürgen (2020): Covid-19 and the informal economy. Impact and response strategies in Sub-Saharan Africa. Berlin: Friedrich Ebert Stiftung (FES), August 2020

Starzmann, Paul (2020): Ewiger Krisenkontinent? Wie afrikanische Politiker in der Coronakrise alte Klischees widerlegen. Berlin: Der Tagesspiegel, 11 May 2020

Taiwo-Obalonye, Juliana (2020): Brexit opportunity to harness human capital in Diaspora NIDCOM. Abuja: The Sun, Nigerian, 6th February 2020

Team 1 (2020): The economic impact of coronavirus on Ghana's economy. Accra: Ghanaian-news, June 7, 2020

Thielke, Tilo (2020): Gefahr auf der Straße - Südafrika will Tausende Gefangene freilassen. Capetown: Frankfurter Allgemeine Zeitung (faz), 14. May 2020

Triebe, Benjamin (2020): London spricht endlich mit Washington über Freihandel - das ist den Brexit nicht wert. Zürich: NZZ, 6 May 2020

Thum, Ulrich (2020): Corona in Nigeria: Mangelnde politische Führung und schlechte Kommunikation. Berlin: Vorwärts, 14. April 2020

Wambu, Wainaina (2020): UK seeks to build Kenya investment ties as Brexit beckons. Nairobi: Standard digital, 22 January 2020

Wane, Fatimata (2020): Brexit : quelles conséquences en Afrique ? Paris: France 24, Le Journal de l'Afrique, 31/01/2020

WHO (2020): COVID-19 - Situation update for the WHO African region - External situation report 7. Geneva: World Health Organization, 15 April 2020

World Bank (2020): World Bank Predicts Sharpest Decline of Remittances in Recent History. Washington D.C.: Press release, April 22, 2020 
Résumé : Bien que la Grande-Bretagne ait jusqu'à présent été la plus durement touchée par la pandémie Corona parmi les États membres de l'UE, Johnson persiste à quitter l'UE fin 2020, quel qu'en soit le coût. Vraisemblablement, la pandémie aura un impact beaucoup plus important sur le commerce africain du Royaume-Uni qu'un Brexit sans accord. En Afrique subsaharienne, l'Afrique du Sud a probablement été le pays le plus durement touché par le Brexit et Corona. Cependant, les pauvres, travaillant principalement dans le secteur informel, étaient plus préoccupés par l'impact économique de la pandémie que par la maladie ellemême. Au Nigeria, beaucoup de gens considéraient Corona comme un fléau pour les riches et l'élite. Le président Buhari a partagé l'orgueil de nombreux Britanniques selon lesquels ils sont moins vulnérables à la pandémie et pourraient continuer avec des plans de haut vol après le Brexit. Le Ghana compte parmi les pays d'Afrique subsaharienne qui ont été les plus durement touchés par la pandémie de Corona. Mais contrairement à l'Afrique du Sud et au Nigeria, les effets directs de la pandémie sur le ralentissement de son économie ne sont pas aussi importants que dans d'autres États africains. Au Kenya, le nombre de décès par effet Corona a été beaucoup plus faible que pour la pandémie de SRAS de 2003, mais la transmission du virus COVID-19 a été nettement plus importante. Néanmoins, de nombreux Kenyans ont vu le Brexit comme une bénédiction déguisée, car ils portaient leur espoir sur le IDE massif des investisseurs britanniques. En tout état de cause, il est clair, sans aucun doute, que ceux qui souffriront le plus des effets combinés de la pandémie Corona et du Brexit en Afrique (et vraisemblablement dans le monde entier) sont les pauvres et les vulnérables.

Zusammenfassung: Obwohl Großbritannien unter den EU-Mitgliedstaaten bislang am stärksten von der Koronapandemie betroffen war, besteht Johnson weiterhin darauf, die EU Ende $2020 \mathrm{zu}$ verlassen, unabhängig von den Kosten. Vermutlich wird die Pandemie einen weitaus größeren Einfluss auf den afrikanischen Handel im Vereinigten Königreich haben als ein No-Deal-Brexit. In Afrika südlich der Sahara war Südafrika sowohl vom Brexit als auch von Corona das vermutlich am stärksten betroffene Land. Die Armen, die hauptsächlich im informellen Sektor tätig sind, waren jedoch mehr besorgt über die wirtschaftlichen Auswirkungen der Pandemie als über die Krankheit selbst. In Nigeria stellten sich viele Menschen Corona als Plage der Reichen und der Elite vor. Präsident Buhari teilte die Hybris vieler Briten, dass sie weniger anfällig für die Pandemie sind und mit hochfliegenden Plänen nach dem Brexit fortfahren könnten. Ghana zählt zu den Ländern in Subsahara-Afrika, die ebenfalls mit am stärksten von der Koronapandemie betroffen sind. Im Gegensatz zu Südafrika und Nigeria sind die direkten Auswirkungen der Pandemie auf den wirtschaftlichen Abschwung jedoch nicht so bedeutend wie in anderen afrikanischen Staaten. In Kenia war die Zahl der Koronatoten viel geringer als bei der SARS-Pandemie von 2003, aber die Übertragung des COVID-19-Virus war signifikant höher. Dennoch sahen viele Kenianer den Brexit als verschleierten Segen an, weil sie ihre Hoffnung auf massive ausländische Direktinvestitionen britischer Investoren setzten. In jeden Fall ist klar, dass diejenigen, die am meisten unter den kombinierten Auswirkungen der Koronapandemie und des Brexit in Afrika (und vermutlich weltweit) leiden müssen, die Armen und Verletzlichen sind. 